\title{
Effect of Frozen Storage Periods and Frying Process on Chemical Composition of the Nile Tilapia Fish (Oreochromus niloticus)
}

\author{
Mohamed HR ${ }^{1 *}$, Hafez $\mathrm{NE}^{2}$, Ibrahim SM${ }^{1}$, Awad $\mathrm{AM}^{\mathbf{2}}$ and El-Lahamy AA ${ }^{\mathbf{1}}$ \\ ${ }^{1}$ Fish Processing and Technology Laboratory, National Institute of Oceanography and Fisheries, Egypt \\ ${ }^{2}$ Department of Food Science and Technology, El-Fayoum University, Egypt \\ *Corresponding Author: Hassan Rabea Mohamed, Fish Processing and Technology Laboratory, Fisheries Division, National Institute of \\ Oceanography and Fisheries, Egypt.
}

Received: April 12, 2019; Published: June 13, 2019

DOI: $10.31080 /$ ASAG.2019.03.0526

\begin{abstract}
Alteration in Moisture, protein, fat and ash contents of Tilapia fish (Oreochromus niloticus) during frozen storage at $-18^{\circ} \mathrm{C}$ for 6 months and their pre frozen fried products were determined. Fish samples were obtained from two resources; (A) farm irrigated by El-Bats discharge and (B) farm irrigated by El-Wadi discharge during June 2016 at Fayoum Governorate, Egypt. Results showed that chemical composition (wet weight) of raw tilapia (A) and (B) samples were moisture $79.41 \%$ and $79.38 \%$, crude protein $18.05 \%$ and $17.89 \%$, lipid 1.06 and $1.07 \%$ and ash content 1.14 and $1.22 \%$, respectively. All of these values were fluctuated based on the alteration occurred in moisture content throughout storage periods extended. On the other hand, it was found values of moisture content decreased while protein, fat and ash contents increased in all fried samples throughout storage periods. In conclusion, although resource of irrigation of fish farms was varied but chemical composition of fish was similar. Changes occurred in chemical composition were affected by the period of storage and frying process. However, tilapia fish was maintained their nutritional value until the end of the frozen storage period.
\end{abstract}

Keywords: Moisture; Protein; Fat and Ash; Tilapia Fish; Frozen Storage and Frying

\section{Introduction}

Global fish production has grown steadily in the last five decades with food fish supply increasing at an average annual rate of 3.2 percent, outpacing world population growth at 1.6 percent. World per capita apparent fish consumption increased from an average of $9.9 \mathrm{~kg}$ in the $1960 \mathrm{~s}$ to $19.2 \mathrm{~kg}$ in 2012 . This impressive development has been driven by a combination of population growth, rising incomes and urbanization, and facilitated by the strong expansion of fish production and more efficient distribution channels [1]. The total quantity of catch fish recorded 1,706,273 tones, while the total quantity of Exports and Imports of fish were 47812 and 311068 tones, respectively. Annual average share per capita of fish was $21.64 \mathrm{~kg}$ [2]. Global changes in consumer lifestyle marked by increasing demand for nutritional and healthy food products have spurred the continuing rise in demand for fresh and ready-tocook fish and fishery products. This rising demand for ready to eat fresh instead of frozen fish requires the use of preservation procedures that can add value and reduce postharvest losses [3-6]. The consumption of processed and frozen food has increased due to the impositions of modern life, where food preparation time is the main factor. The temperature and time required to process food, as also the transport and storage conditions, are some of the factors which can contribute to fatty acid and cholesterol degradation [7]. Concern, thermal processing techniques (smoking, frying....etc.), they are widely used to improve eating quality and safety of food products and to extend the shelf life of the products. Fish and fishery products are cooked in different ways to improve its hygienic quality by inactivation of pathogenic micro-organisms and to enhance its flavor and taste. During cooking, chemical and physical reactions take place which either improve or impair the food nutritional value (e.g., digestibility is increased because of protein denaturation in food) but the contents of thermo labile compounds, fatsoluble vitamins or polyunsaturated fatty acids are often reduced [8-10]. Fish frying is one of the oldest methods of food preparation. It improves the sensory quality of food by formation of aroma compounds, attractive color, crust and texture. Deep fat frying is a process where in a food is allowed to be immersed and held in hot fat for cooking. Fried foods have a distinct position, attributed to their characteristic color, flavor and aroma. During this process, complex operations could occur involving numerous chemical and physical 
changes such as starch gelatinization, protein denaturation, moisture evaporates and forming coating [11].

The main objective of the current study could be summarized in studying the effect of frozen storage conditions at $-18^{\circ} \mathrm{C}$ for 180 days on the Chemical Composition of Tilapia Fish their pre Frozen Fried Products.

\section{Material and Methods}

Materials

Fish samples

About $20 \mathrm{~kg}$ of Tilapia (O. niloticus) fish samples were obtained from different two farms (A and B) during, June 2016 at Fayoum Governorate, Egypt. The averages of weight and length were $303 \pm 31.5 \mathrm{~g}$ and $25.9 \pm 0.22 \mathrm{~cm}$ for raw samples obtained farm A irrigated by Al-Batts Drain, while, the corresponding values for samples from farm B irrigated by El-Wadi Drain were $327 \pm 93.8 \mathrm{~g}$ and $26 \pm 2.8 \mathrm{~cm}$, respectively.

\section{Sunflower oil}

Sunflower oil was purchased from the local market at Fayoum governorate, it contained: saturated fat (12.85\%); polyunsaturated fatty acid (60\%); monounsaturated fatty acid $(27.14 \%)$ and produced by Arma for food Industries Company.

\section{Freezing}

Fish samples were transported using ice box to Fish Processing and Technology Laboratory, Shakshouk research Station for Aquatic Resources, National Institute of Oceanography and Fisheries (NIOF). Fish samples were carefully washed with tap water, glazed, packed in polyethylene bags and stored at $-18^{\circ} \mathrm{C}$ for 6 months.

\section{Frying process}

The prepared fish was rubbed with flour left for 3-4 min and fried in pre-heated deep fried oil at $170-180^{\circ} \mathrm{C}$ for $10-15 \mathrm{~min}$ using Electrical Fryer pan (Moulinex brand). Fried fish samples were removed when a golden brown color was appeared on their surfaces. They were placed in the frying basket to drain out the excess amounts of cooking oil then cooled and kept for analysis of chemical composition.

\section{Analytical methods}

Chemical compositions (moisture, protein, fat and ash contents) for raw, frozen and fried tilapia fish samples at intervals of $0,2,4$ and 6 months of storage were determined according to AOAC [12]. All the results were triplicates and expressed as mean \pm SD.

\section{Statistical Analysis}

The statistical analysis of the results obtained was carried out according to SPSS version 16 software program 2007. Means and standard deviation (SD) measure by L.S.D at $5 \%$ level of significant.

\section{Results and Discussion}

Moisture content

Data presented in Table 1 shows the effect of frozen storage at $-18^{\circ} \mathrm{C}$ for 180 days followed by frying of tilapia fish samples on the moisture content. Moisture content of raw tilapia samples (A and B) recorded $79.41 \%$ and $79.38 \%$, respectively. Based on these results, it could be noticed the irrigation resource of fish farms did not affect water content of different fish samples. Concerning the effect of frozen storage conditions, a negligible decrease in moisture content of fish samples (A) at 60 days and little increased at 120 and 180 days. On the other hand, moisture content of fish samples (B) was taken the same trend exception it gradually decreased up to 120 days storage. It could be noticed that with regard to the effect of frying process, moisture content of fresh tilapia decreased after frying from $79.41 \%$ to $63.21 \%$ for samples from farm A and from $79.38 \%$ to $68.09 \%$ for samples from farm B, respectively. These results agree with Ibrahim and El-Sherif [13] who found that the moisture content of raw tilapia fish was $78.3 \%$ reduced to $63.22 \%$ after deep-frying in sunflower oil at $160 \mathrm{C}$ for $10 \mathrm{~min}$. The same trend found by Suwanchongsatit., et al. [14] who found the Sepat-Siam fish (Trichogas terpectoralis) or leaf fish samples contained $78.35 \%$ of moisture and decreased to $62.31 \%$ after atmospheric deep-frying at $170^{\circ} \mathrm{C}$ for 10 minutes. They also reported that moisture content of fried fish declined when frying times and frying temperatures increased. Also Bilgin., et al. [15] reported that the moisture content of raw rainbow trout was $73.78 \%$ and reduced to 59.72 and $63.26 \%$ after deep frying in sunflower oil and margarine respectively. Similar results were found by Gladyshev., et al. [16] who observed that the moisture content of raw zander fish was $79.7 \%$ and reduced to $63.8 \%$ after frying. After 60 days from frozen storage the moisture content decreased to 78.81 and 87.49\% for samples from farms A and B, respectively. After frying moisture values decreased to 71.96 and $67.21 \%$ for farms A and B samples, respectively. Our results agree with Ojagh., et al. [17] who found that the moisture content of silver carp nuggets prefried was $67.41 \%$ at $170^{\circ} \mathrm{C}$, and they reported that moderate temperature of $170^{\circ} \mathrm{C}$ retains more moisture and increases the water holding capacity. The reduction in moisture content is an advantage since it reduced the fish susceptibility to microbial spoilage, oxidative degradation of polyunsaturated fatty acids, and consequently it improves fish quality and preservation [18]. Moisture content increased to $79.05 \%$ in frozen samples form farm A after 120 days. On the other hand the moisture content decreased to $77.01 \%$ in farm B frozen samples at the same storage period compared with previous period. After frying the moisture content decreased in both farms samples and reached to 72.84 and 70.54 for farms A and B, respectively. Our results agreed with Marimuthu., et al. [19] who reported that the moisture content of snakehead fish (C. striatus) was 77.2 and reduced to $71.6 \%$ after frying. The mobility of material and exit of moisture during the frying process 


\begin{tabular}{|l|c|c|c|c|}
\hline \multirow{2}{*}{ Period of storage (day) } & \multicolumn{4}{|c|}{ Moisture content \% (ww) } \\
\cline { 2 - 5 } & \multicolumn{2}{|c|}{ Farm A (Al-Batts drain) } & \multicolumn{2}{c|}{ Farm B (El-Wadi drain) } \\
\cline { 2 - 5 } & Frozen fish & Fried fish & Frozen fish & Fried fish \\
\hline 0 & $79.41 \pm 0.29$ & $63.21 \pm 0.15$ & $79.38 \pm 0.35$ & $68.09 \pm 0.27$ \\
\hline 60 & $78.81 \pm 0.93$ & $71.96 \pm 0.82$ & $78.49 \pm 0.55$ & $67.21 \pm 0.41$ \\
\hline 120 & $79.05 \pm 0.16$ & $72.84 \pm 0.16$ & $77.01 \pm 0.70$ & $70.54 \pm 0.25$ \\
\hline 180 & $80.17 \pm 0.35$ & $73.97 \pm 0.36$ & $78.04 \pm 0.24$ & $73.83 \pm 0.17$ \\
\hline
\end{tabular}

Table 1: Moisture content (\%) $(\mathrm{M} \pm \mathrm{SD})$ of frozen stored Tilapia fish at $-18^{\circ} \mathrm{C}$ for 180 days and their fried products.

Farm A = Al-Batts Drain. Farm B = El-Wadi Drain. M: Mean. SD: Standard Deviation.

caused decreasing the moisture content [17]. Offer., et al. [20] reported that the most water in muscle is held within the myofibrils, in the space between the thick filaments (myosin) and thin filaments (actin) and some water is located in the connective tissue. As cooking proceeded, heat induced protein denaturation and aggregation leading to shrinkage of both the filament lattice and the collagen and also to exposition of hydrophobic areas of the myofibrillar structure, which allow new intra and inter- protein interactions that resulted in a more dense protein structure [21]. Hence, water was pressed out of the muscle cells leading to water loss. At the end of frozen storage period the values of moisture content was slightly increased in samples from both farms. The moisture contents recorded 80.17 and 78.04 for frozen tilapia samples from farms A and B, respectively. While these values were decreased after frying to 73.97 and $73.83 \%$ for farm A and B respectively. Siddique., et al, [22] have shown that flesh moisture content increases with freezing time. Zamir., et al. [23] attributed this increase to the loss of water-holding capacity of the tissue. Fish with higher flesh moisture content have a higher proportion of loosely bound water [24]. The moisture loss during frying in vegetable oils was reported for some other fish species [25-29].

\section{Protein content}

The higher crude protein content in fish is important from the dietary point of view since; the quality of fish protein is very high because of its essential amino acid composition. Further, reports also indicate that fish muscle is more digestible than other animal protein due to lower level of connective tissue [30]. The relatively high crude protein in freshwater fishes could be attributed to the fact that fishes are good source of pure protein [31]. Indeed the protein content of the species is higher than that of the egg yolk (15\%) reported by CFCD [32]. normal range values of protein in fish (15-25\%), and the variation in protein content could be due to the variation in species, feed availability, sexual maturity, spawning, season of catching and processing methods. The changes in protein content during frozen storage at $-18^{\circ} \mathrm{C}$ for 180 days followed by frying of tilapia fish samples obtained from farms A and B are illustrated in Table 2. Protein contents of fresh tilapia fish was
18.05 and $17.89 \%$ for farm A and B respectively. After frying protein content was increased to 25.85 and $24.69 \%$ for samples from farms A and B, respectively. The same trend was obtained by Ibrahim and El-Sherif [13]. They found that the protein content of three fish species, mullet, tilapia and silver carp were 18.35, 18.15 and $17.85 \%$ respectively which increased after frying to $28.25,27.85$ and $28.13 \%$ respectively. After 60 days of frozen storage the protein content increased to $18.22 \%$ in farm A frozen samples, while protein content decreased to $17.72 \%$ in farm B frozen samples. After frying the values of protein increased to 22.59 and $23.62 \%$ for samples from farms A and B, respectively. Arannilewa., et al. [33] reported that protein content of fresh Nile tilapia (Sarotherodun galiaenus) was $60.65 \%$ (dry wt.) and decrease to 57.7 and $43.7 \%$ after 1 and 2 months of frozen storage, respectively. After 120 days of frozen storage, protein content slightly decreased to $18.20 \%$ for samples from farm A then increased after deep frying to $22.0 \%$ for samples from farm $A$. in other hand protein content increased to 19.19 in frozen tilapia fish samples obtained from farm B, after frying protein content increased to $22.63 \%$. Same trend found by Marimuthu., et al. [19] who reported that the protein content of snakehead fish (C. striatus) was $13.9 \%$ and increased to $17.3 \%$ after frying. At the end of frozen storage (180 days), protein content of frozen samples from farms, decreased to 17.01 and $18.69 \%$ for samples from farm A and B, respectively. After frying these values increased to 21.20 and $21.21 \%$ for farm A and B respectively. Our results agree with Uran and Gokoglu [34] who reported that the protein content of raw anchovy was $18.6 \%$ and after frying the protein increased to $20.2 \%$. Siddique., et al. [22] reported significant decrease in protein content during frozen storage of fish. Jenkelunas [35] showed that Muscle protein stored at freezing temperatures will incur damage due to ice crystal formation [36]. As water molecules freeze, they begin to migrate away from the protein into ice crystals, thus exposing hydrophobic and hydrophilic areas and allowing intra- and intermolecular cross linkages [37]. Jenkelunas [35] reported that the native structure of a protein is usually the most stable conformation under normal physiological conditions [38]. However, during frozen storage proteins are susceptible to 


\begin{tabular}{|l|c|c|c|c|}
\hline \multirow{2}{*}{ Period of storage (days) } & \multicolumn{4}{|c|}{ Protein content \% (ww) } \\
\cline { 2 - 5 } & \multicolumn{2}{|c|}{ Farm A } & \multicolumn{2}{c|}{ Farm B } \\
\cline { 2 - 5 } & Frozen fish & fried fish & Frozen fish & fried fish \\
\hline 0 & $18.05 \pm 0.25$ & $25.85 \pm 0.77$ & $17.89 \pm 0.80$ & $24.69 \pm 1.00$ \\
\hline 60 & $18.22 \pm 0.46$ & $22.59 \pm 1.00$ & $17.72 \pm 0.59$ & $23.62 \pm 0.31$ \\
\hline 120 & $18.20 \pm 0.05$ & $22.00 \pm 0.56$ & $19.19 \pm 0.26$ & $22.63 \pm 0.80$ \\
\hline 180 & $17.01 \pm 0.69$ & $21.20 \pm 0.56$ & $18.69 \pm 0.41$ & $21.21 \pm 1.00$ \\
\hline
\end{tabular}

Table 2: Protein content $(\%)(\mathrm{M} \pm \mathrm{SD})$ of frozen stored Tilapia fish at $-18^{\circ} \mathrm{C}$ for 180 days their fried products.

Farm A = Al-Batts Drain. Farm B = El-Wadi Drain. M: Mean. SD: Standard Deviation.

denaturation. The rate at which muscle protein denatures varies among species. Fish myofibrillar proteins, despite having similar amino acid composition to the proteins from mammalian fish species, they are much less stable than the latter [39].

\section{Lipid content}

Data presented in Table 3 show the effect of frozen storage at $-18^{\circ} \mathrm{C}$ for 180 days followed by deep frying at $170^{\circ} \mathrm{C}$ for $10 \mathrm{~min}$ on the lipid content of tilapia fish samples obtained from farms $\mathrm{A}$ and B. Lipid contents of fresh tilapia fish were 1.06 and $1.07 \%$ for samples from farms A and B, respectively. After frying the lipid content increased to 9.43 and $5.57 \%$ for samples from farms A and B, respectively. According to Ackman [40], fish can be grouped into four categories according to their fat content: lean fish $(<2 \%)$, low fat (2 to $4 \%$ ), medium fat (4 to $8 \%$ ), and high fat (> 8\%). According to this classification the tilapia fish used in this work is considered lean fish (<2\% fat). Our results agreed with Khidhir, et al. [41] who reported that the values of fat content of Rainbow trout and Tilapia muscles ranged between $1.05-1.29 \%$, they also showed that the fat content means values were $1.665 ; 1.048 ; 2.008$ and $1.523 \%$ for Myanmar, Flander, Hasoon and White fish fillet respectively. After 60 days of frozen storage the lipid content increased to $1.74 \%$ and $2.82 \%$ for samples from farms A and B, respectively. Also af- ter frying these values increased to 4.83 and $8.23 \%$ for samples from farms A and B, respectively. According to Suwanchongsatit., et al. [14] and Bilgin., et al. [15] the atmospheric deep-frying of fish had increasing fat content as frying times and frying temperatures increased. After 120 days of frozen storage, the lipid content decreased to 1.46 and $1.68 \%$ for samples from farms A and B, respectively. On contrast the lipid values were increased after frying to 4.32 and $4.64 \%$ for samples from farms A and B, respectively. Bilgin., et al. [15] reported that fried fish had a higher level of fat than raw fish, mainly due to the absorption of fat by the fish. The absorption of fat through frying also caused an increase of dry matter. Garcia-Arias., et al. [9] and Gokoglu., et al. [42] have also reported similar findings. Türkkan., et al. [43] found a decrease in moisture, an increase in ash and fat after frying in Seabass. At the end of frozen storage, the lipid content increased to 2.53 and $2.73 \%$ for samples from farms A and B, respectively. After frying these values were increased to 4.49 and $3.83 \%$ for samples from farms A and B, respectively. The increase of lipid content can be attributed to the oil penetration on the food after water is partially lost by evaporation [11,44]. Also Gokoglu., et al. [42] reported significantly higher lipid content in fried fish than in raw fish. Same results obtained by Ibrahim and El-Sherif [13] who found that lipid content of mullet, tilapia and silver carp fish were $3.45,2.20$ and $2.88 \%$, after frying increased to $6.52,5.80$ and $5.80 \%$, respectively.

\begin{tabular}{|c|c|c|c|c|}
\hline \multirow{2}{*}{$\begin{array}{c}\text { Period of storage } \\
\text { (days) }\end{array}$} & \multicolumn{3}{|c|}{ Lipid content \% (ww) } \\
\cline { 2 - 5 } & Frozen fish & Fried fish & Frozen fish & Fried fish \\
\cline { 2 - 5 } & $1.12 \pm 0.09$ & $9.43 \pm 0.32$ & $1.23 \pm 0.19$ & $5.57 \pm 0.20$ \\
\hline 0 & $1.74 \pm 0.08$ & $4.83 \pm 0.070$ & $2.82 \pm 0.02$ & $8.23 \pm 0.15$ \\
\hline 60 & $1.46 \pm 0.18$ & $4.32 \pm 0.12$ & $1.68 \pm 0.19$ & $4.64 \pm 0.25$ \\
\hline 120 & $2.53 \pm 0.13$ & $4.49 \pm 0.19$ & $2.73 \pm 0.35$ & $3.83 \pm 0.24$ \\
\hline
\end{tabular}

Table 3: Lipid content $(\%)(\mathrm{M} \pm \mathrm{SD})$ of frozen stored Tilapia fish at $-18^{\circ} \mathrm{C}$ for 180 days and their fried products Farm A = Al-Batts Drain. Farm B = El-Wadi Drain. M: Mean. SD: Standard Deviation. 


\section{Ash content}

Table 4 shows the values of ash contents of fish samples obtained from farms $\mathrm{A}$ and $\mathrm{B}$ during frozen storage of tilapia at $-18^{\circ} \mathrm{C}$ for 180 days and their pre frozen deep fried products at $170^{\circ} \mathrm{C}$ for $10 \mathrm{~min}$. From the table the ash content of fresh tilapia from farms A and $B$ were 1.14 and $1.22 \%$ respectively. These values increased after deep frying to 1.29 and $1.52 \%$ for samples from farms A and B, respectively. Same results were found by Uran and Gokoglu [34] who found that ash content of raw anchovy was $1.2 \%$ and increased to 1.4 after frying. Also Bilgin., et al. [15] reported that the ash content of raw rainbow trout was 1.43 and increased to $1.92,1.86$ and 1.82 after frying in olive oil, sunflower oil and corn oil, respectively. After 60 days the values of ash slightly decreased in both samples from farms A and B which recorded 1.1 and $1.07 \%$, respectively and after frying, these values increased to 1.13 and $1.43 \%$. The same trend was found by Gandotra., et al. [45] who reported that the ash content decreased during freezing of fish from $1.7 \%$ to $1.3 \%$. Arannilewa., et al. [33] observed that the ash content remained almost the same throughout the 60 days of frozen storage of tilapia. Ash content increased after 120 days in frozen samples from the two farms A and B. the values were 1.13 and $1.26 \%$ respectively. After frying the values of ash content decreased to $1.08 \%$ for farm A samples, while increased to $1.27 \%$ for farm B samples. At the end of storage the values of ash content decreased in frozen samples to 1.07 and $1.20 \%$ for samples from farms A and B, respectively. The same trend was observed after frying, the ash content decreased to 1.04 and $1.1 \%$ for samples from farms A and B, respectively. Our results agree with Emire., et al. [46] who reported that the ash content of Tilapia, (Oreochromis niloticus) decrease during its frozen storage. The decrease in ash content was attributed to the drip loss during thawing process by Beklevik., et al. $[47,48]$.

\begin{tabular}{|l|c|c|c|c|}
\hline \multirow{2}{*}{$\begin{array}{c}\text { Period of } \\
\text { storage } \\
\text { (days) }\end{array}$} & \multicolumn{4}{|c|}{ Ash content \% (ww) } \\
\cline { 2 - 5 } & Frozen fish & Fried fish & Frozen fish & Fried fish \\
\hline 0 & $1.14 \pm 0.07$ & $1.29 \pm 0.04$ & $1.22 \pm 0.08$ & $1.52 \pm 0.04$ \\
\hline 60 & $1.1 \pm 0.14$ & $1.13 \pm 0.02$ & $1.07 \pm 0.13$ & $1.43 \pm 0.18$ \\
\hline 120 & $1.13 \pm 0.07$ & $1.08 \pm 0.05$ & $1.26 \pm 0.02$ & $1.27 \pm 0.01$ \\
\hline 180 & $1.07 \pm 0.02$ & $1.04 \pm 0.06$ & $1.20 \pm 0.08$ & $1.1 \pm 0.05$ \\
\hline
\end{tabular}

Table 4: Ash content $(\%)(\mathrm{M} \pm \mathrm{SD})$ of frozen stored Tilapia fish at $-18^{\circ} \mathrm{C}$ for 180 days and their fried products.

Farm A = Al-Batts Drain. Farm B = El-Wadi Drain. M: Mean. SD: Standard Deviation.

\section{Conclusion}

Also, although resource of irrigation of farms was varied but chemical composition of fish was similar. Changes occurred in chemical composition were affected by the period of storage and frying process. Proximate composition of tilapia fish showed significant differences between raw and fried samples during frozen storage periods. However, tilapia fish was maintained their nutritional value until the end of the frozen storage period.

\section{Bibliography}

1. FAO Food and Agricultural Organization. "Post-harvest changes in fish. Fisheries and Aquaculture Department". Food and Agriculture Organization of the United Nations (2014).

2. GAFRD. "General Authority of Fish Resources Development". Fish Statics Year Book. Ministry of agriculture, Egypt (2016).

3. Trondsen T., et al. "Perceived barriers to consumption of fish among Norwegian women”. Appetite 41.3 (2003): 301-314.

4. De Silva DAM and Yamao M. "Regional preferences in the Japanese Seafood consumption: An empirical analysis of consumer purchasing behaviour on domestic versus imported seafood". Japan, Journal of the Regional Fisheries Society 46 (2006): 83104.

5. Opara U L. "Quality management: an industrial approach to produce handling. In: Postharvest handling". A systems approach (edited by W. J. Florkowski, S. E. Prussia, R. L. Shewfelt and B. Brueckner). USA: Academic Press (2009): 153-204.

6. Speranza B., et al. "Microbiological and sensorial quality assessment of ready-to-cook seafood products packaged under modified atmosphere". Journal of Food Science 74.9 (2009): 473-478.

7. Li S X., et al. "Storage, heating, and tocopherols affect cholesterol oxide formation in food oils". Journal of Agricultural and Food Chemistry 44.12 (1996): 3830-3834.

8. Bognár A. "Comparative study of frying to other cooking techniques. Influence of the nutritive value". Grasasy Aceites 49.3-4 (1998): 250-260.

9. Garcia-Arias MT., et al. "Cooking-freezing-reheating (CFR) of sardine (Sardina pilchardus) fillets effect of different cooking and reheating procedures on the proximate and fatty acid compositions". Journal of Food Chemistry 83 (2003): 349-356. 
10. Alizade E., et al. "Effect of freezing and cooking processes on the texture of Atlantic salmon (Salmo salar) Fillets". Proceedings of the 5th CIGR Section VI International Symposium on Food Processing, Monitoring Technology in Bioprocesses and Food Quality Management. Potsdam, Germany (2009): 262269.

11. Dana D and Saguy S. "Review: Mechanism of oil uptake during deep-fat frying and the surfactant effect-theory and myth". Journal of Advances in Colloid and Interface Science 128-130: (2006): 267-272.

12. AOAC. "Association of official analytical chemists. Official methods of analysis". 19th edition, suite 500, 481 north Frederick Avenue, Gaithersburg, Maryland (2012): 20877-2417.

13. Ibrahim S M and El-Sherif S A. "Effect of some cooking methods on pollutants in fish obtained Wadi El rayan Lake". Project report, Fish Processing and Technology Lab., Fisheries Division, National Institute of Oceanography and Fisheries, Egypt (2016).

14. Suwanchongsatit W., et al. "Frying Process Improvement and Shelf Life Studies of Fried Boneless Salted Sepat-Siam". Kasetsart Journal 38.6 (2004): 142-149.

15. Bilgin E., et al. "Effects of pan frying with different oils on some of the chemical components, quality parameters and cholesterol levels of rainbow trout (Oncorhynchus mykiss)". African Journal of Biotechnology 9.39 (2010): 6573-6577.

16. Gladyshev M I., et al. "Effect of the Way of Cooking on Contents of Essential Polyunsaturated Fatty Acids in Filets of Zander". Czech Journal of Food Sciences 32.3 (2014): 226-231.

17. Ojagh S M., et al. "The Effect of Different Pre-Fried Temperatures on Physical and Chemical Characteristics of Silver Carp Fish(Hypophthalmichthys molitrix) Nuggets". World Journal of Fish and Marine Sciences 5.4 (2013): 414-420.

18. Allen JC. "Industrial aspects of lipids oxidation: In Recent Advances in Chemistry and Technology of Fats and Oil". Hamilton RJ, Bhati A, Eds, Elsevier, London (1987): 31-39.

19. Marimuthu K., et al. "Effect of different cooking methods on proximate and mineral composition of striped snakehead fish (Channa striatus, Bloch)". Journal of Food Science and Technology 49.3 (2012): 373-377.
20. Offer G., et al. "The structural basis of the water-holding, appearance and toughness of meat and meat products". Journal of Food Microstruct 8.1 (1989): 151-170.

21. Straadt I K., et al. "Aging-induced changes in microstructure and water distribution in fresh and cooked pork in relation to water-holding capacity and cooking loss A combined confocal laser scanning microscopy (CLSM) and low-field nuclear magnetic resonance relaxation study". Journal of Meat Science 75.4 (2007): 687-695.

22. Siddique M N., et al. "Effect of freezing time on nutritional value of Jatpunti (Puntius sophore), Sarpunti (P. sarana) and Thaisarpunti (P. gonionotus)". Bangladesh Research Publications J. 5.4 (2011): 387-392.

23. Zamir M., et al. "Changes in physical and chemical constituents of crab meat during storage at refrigerator temperature $\left(7 \pm 2^{\circ} \mathrm{C}\right)$ ". Pakistan Journal of Pharmaceutical Sciences 11.1 (1998): 27-33.

24. Odoli C O. "Optimal storage conditions for fresh farmed tilapia (Oreochromis niloticus) fillets". Doctoral dissertation. University of Iceland (2009).

25. Gladyshev MI., et al. "Effect of boiling and frying on the content of essential polyunsaturated fatty acids in muscle tissue of four fish species". Food Chemistry 101 (2007): 1694-1700.

26. Gladyshev M I., et al. "Effect of way of cooking on content of essential polyunsaturated fatty acids in muscle tissue of humpback salmon (On-corhynchus gorbuscha)". Food Chemistry 96.3 (2006): 446-451.

27. Mnari A B., et al. "Nutritional fatty acid quality of raw and cooked farmed and wild sea bream (Sparus aurata)". Journal of Agricultural and Food Chemistry 58.1 (2010): 507-512.

28. Zhang H B., et al. "Distributions and Concentrations of PAHs in Hong Kong Soils". Environmental Pollution 141 (2006): 107114.

29. Zotos A., et al. "Effect of baking of sardine (Sardina pilchardus) and frying of anchovy (Engraulis encrasicholus) in olive and sunflower oil on their quality". Food Science and Technology International 19.1 (2013): 11-23. 
30. Abdulrahman MO and D'Souza R. "The effects of different methods of cooking on proximate, mineral and heavy metal composition of fish and shrimps consumed in the Arabian Gulf". Latin American Archivos of Nutricion Organo Oficial of the Sociedad Latinoamericana de Nutrición 58.1 (2008):103109.

31. Burgess GHO. "Increasing the direct consumption of fish". In: W.W. Pirie (ed.). Food Protein Sources. Int. Biological Programme 4. Cambridge University Press, Cambridge, (1975): 187-200.

32. CFCD. "China food composition data base (CD-ROM)". Institute of Nutrition and Food Safety China CDC, Beijing (2002).

33. Arannilewa ST., et al. "Effect of frozen period on the chemical, microbiological and sensory quality of frozen, tilapia fish (Sarotherodun galiaenus)". African Journal of Biotechnology 4.8 (2005): 852-855.

34. Uran H and Gokoglu N. "Effects of cooking methods and temperatures on nutritional and quality characteristics of anchovy (Engraulis encrasicholus)". Journal of Food Science and Technology 51.4 (2014): 722-728.

35. Jenkelunas, P. "Production and Assessment of Pacific Hake Hydrolysates as a Cryoprotectant for Frozen Fish MinceM.Sc". Thesis. Food Science,University of British Columbia (2013).

36. Howell B K., et al. "Thermal-stability of fish myofibrils - a differential scanning calorimetric study". International Journal of Food Science and Technology 26.3 (1991): 283-295.

37. Matsumoto J. "Chemical denaturation of muscle proteins during frozen storage”, In: J.R. Whitaker, and M. Fujimaki (Eds.), Chemical Deterioration of Proteins, 95-124. Washington, D.C. American Chemical Society Publications.

38. Dobson CM. "Principles of protein folding, misfolding and aggregation”. Seminars in Cell \& Developmental Biology 15.1 (2004): 3-16.

39. Connell JJ. "Relative stabilities of skeletal-muscle myosins of some animals". Biochemical Journal 80.3 (1961): 503-509.

40. Ackman R. "Fatty acids". In: Marine Biogenic Lipids, Fats and Oils (edited by R..Ackman). CRC Press, Boca Raton: CRC Press (1989): 103-137.
41. Khidhir Z K., et al. "Qualitative Assessment of Imported Frozen Fish Fillets In Sulaimani Markets". Iraqi Journal of Veterinary Sciences 27.1 (2013): 49-55.

42. Gokoglu N., et al. "Effects of cooking methods on the proximate composition and mineral contents of rainbow trout (Oncorhynchus mykiss)". Food Chemistry 84.1 (2004):19-22.

43. Türkkan A U., et al. "Effects of cooking methods on the proximate composition and fatty acid composition of seabass (Dicentrarchus labrax, Linnaeus, 1758)". Food and Bioproducts Processing 86.3 (2008): 163-166.

44. Erkan N., et al. "Amino acid and vitamin composition of raw and cooked Horse Mackerel". Food Analytical Methods 3.3 (2010): 269-275.

45. Gandotra R., et al. "Effect of Chilling and Freezing on Fish Muscle". IOSR Journal of Pharmacy and Biological Sciences (IOSRJPBS) 2.5 (2012): 05-09.

46. Emire SA and Gebremariam MM. "Influence of frozen period on the proximate composition and microbiological quality of Nile Tilapia fish (oreochromis niloticus)". Journal of Food Processing and Preservation 34.4 (2010): 743-757.

47. Beklevik G., et al. "Nutritional value of Sea Bass (Dicentrarchus labrax) fillets during frozen(-18c) storage". Turkish Journal of Veterinary And Animal Sciences 29 (2005): 891- 895.

48. Da Silva LVA. "Hazard analysis critical control point (HACCP), microbial safety, and shelf life of smoked blue catfish (Ictalurus furcatus)". Master Thesis, Louisiana State University (2002): 100.

\section{Volume 3 Issue 7 July 2019 \\ (C) All rights are reserved by Mohamed HR, et al.}

